\title{
Some Physical Properties of Rice Ragged Stunt Virus
}

\author{
Toshihiro SenвokU*, Tyng-Guang ChоU*, and Eishiro ShiкAтA* \\ 仙北俊弘*・周 廷光* ・四方英四郎* : イネ ragged stunt ウイルスの物理的諸性質
}

Rice ragged stunt disease was first reported in Indonesia and the Philippines. Hibino et al. ${ }^{1)}$, Ling ${ }^{2)}$, and Ling et al. ${ }^{3)}$ described the characteristic symptoms on rice and the transmission mode by brown planthopper (Nilaparvata lugens Stål). Electron microscopy of purified and dip preparations revealed isometric particles of $50-70 \mathrm{~nm}$ in diameter ${ }^{4)}$. Recently, success of artificial injection of the virus into the insects has been reported ${ }^{5)}$. This paper reports some physical properties of rice ragged stunt virus (RRSV) using insect injection method.

Virus-free brown planthoppers used in this experiment, that were collected in Japan, were offered by Dr. Kishimoto, Central Agricultural Experiment Station (Konosu, Saitama, Japan) and maintained over 5 years in the greenhouse of the Department of Botany, Faculty of Agriculture, Hokkaido University, Sapporo, Japan. Originally, the diseased rice plants (IR 3839-1) were offered by Dr. K. C. Ling, International Rice Research Institute (Philippines), and the virus maintained on diseased japonica rice plants (Mihonishiki) inoculated by viruliferous brown planthoppers which had fed on a disease rice plant (IR 3839-1). Extracts from the diseased rice plants grown for 1-2 months after inoculation, and from the viruliferous brown planthoppers confined for 2 weeks after 2 days acqusition feeding were used for injection. These materials were ground in $0.1 \mathrm{M}$ ammonium acetate buffer ( $\mathrm{pH} 7.0$ ) in most case, and centrifuged at $3,000 \mathrm{rpm}$ for $10 \mathrm{~min}$. The resultant supernatants were injected into insects for infectivity assay. The injected insects were fed on healthy rice plants for 11 days, and then transfered individually to healthy young rice seedlings in test tubes for inoculation. After 3 days, they were transfered to another test plants for 3 days.

Table 1. Effect of buffers on RRSV in crude sap

\begin{tabular}{l|c|c|c|c}
\hline \hline Buffers (pH 7.0) & $\begin{array}{c}\text { No. of insects } \\
\text { injected }\end{array}$ & $\begin{array}{c}\text { No. of insects } \\
\text { survived } \\
\text { for 11 days }\end{array}$ & $\begin{array}{c}\text { No. of insects } \\
\text { infected }\end{array}$ & $(\%)$ \\
\hline $0.1 \mathrm{M}$ phosphate & 40 & 12 & 10 & $(83)$ \\
$0.2 \mathrm{M}$ phosphate & 40 & 12 & 9 & $(75)$ \\
$0.1 \mathrm{M}$ ammonium & 40 & 15 & 12 & $(80)$ \\
acetate & 40 & 15 & 13 & $(87)$ \\
Distilled water & 40 & 13 & 7 & $(54)$ \\
\hline
\end{tabular}

The inoculated plants were transplanted to soil in the temperature controlled greenhouse at $25 \mathrm{C}$.

Effect of Buffers. Four kinds of buffer solutions at $\mathrm{pH} 7.0$, such as $0.1 \mathrm{M}$ and $0.2 \mathrm{M}$ phosphate buffers, $0.1 \mathrm{M}$ ammonium acetate buffer, and $0.05 \mathrm{M}$ Tris buffer were used. Distilled water was used as

* Faculty of Agriculture, Hokkaido University, Sapporo 060, Japan 北海道大学農学部

1) Hibino, H., M. Roechan, S. Sudarisman, and D. M. Tantera. (1977). Contr. Centr. Res. Inst. Agric. Bogor $35: 1-15$. 2) Ling, K. C. (1977). Int. Rice Res. Newsl. 2 (5) : 6-7. 3) Ling, K. C., E. R. Tiongco, and V. M. Aguiero. (1978). Plant Dis. Reptr. 62:701-705. 4) Shikata, E., K. Leelapanang, E. R. Tiongco, and K. C. Ling. (1977). Int. Rice Res. Newsl. 2(5): 7. 5) Senboku, T., E. Shikata, E. R. Tiongco, and K. C. Ling. (1978). Int. Rice Res. Newsl. 3(2) : 8. 
Table 2. Longevity in vitro of RRSV at $4 \mathrm{C}$

\begin{tabular}{c|c|c|c|c}
\hline \hline Days & $\begin{array}{c}\text { No. of insects } \\
\text { injected }\end{array}$ & $\begin{array}{c}\text { No. of insects } \\
\text { survived } \\
\text { for 11 days }\end{array}$ & $\begin{array}{c}\text { No. of insects } \\
\text { infected }\end{array}$ & $(\%)$ \\
\hline (control) & 60 & 23 & 15 & $(65)$ \\
1 & 60 & 13 & 5 & $(39)$ \\
2 & 60 & 19 & 13 & $(68)$ \\
3 & 60 & 36 & 25 & $(69)$ \\
4 & 60 & 16 & 4 & $(25)$ \\
5 & 60 & 18 & 3 & $(17)$ \\
6 & 60 & 28 & 3 & $(11)$ \\
7 & 60 & 17 & 1 & $(6)$ \\
\hline
\end{tabular}

control. Diseased leaves were ground in 2 volumes $(\mathrm{v} / \mathrm{w})$ of each buffer and the extracts were injected into insects. As shown in Table 1, the infectivity of RRSV in the crude sap expressed in these buffers at $\mathrm{pH} 7.0$ did not differ markedly.

Longevity in vitro. In order to know the longevity of the virus in crude sap, the diseased leaves were macerated in 2 volumes $(\mathrm{v} / \mathrm{w})$ of $0.1 \mathrm{M}$ ammonium acetate buffer. The extract was stored at $4 \mathrm{C}$ and injected into healthy insects every

Table 3. Dilution end point of RRSV

\begin{tabular}{|c|c|c|c|c|c|c|c|c|c|}
\hline Virus source & Dilution & $10^{-1}$ & $10^{-2}$ & $10^{-3}$ & $10^{-4}$ & $10^{-5}$ & $10^{-6}$ & $10^{-7}$ & $10^{-8}$ \\
\hline Planthoppers & $\begin{array}{c}\text { No. of insects injected } \\
\text { No. of insects survived } \\
\text { for } 11 \text { days } \\
\text { No. of insects infected } \\
(\%)\end{array}$ & $\begin{array}{l}- \\
- \\
-\end{array}$ & - & $\begin{array}{l}- \\
- \\
-\end{array}$ & $\begin{array}{r}50 \\
21 \\
6 \\
(29)\end{array}$ & $\begin{array}{r}50 \\
25 \\
2 \\
(8)\end{array}$ & $\begin{array}{r}50 \\
25 \\
3 \\
(12)\end{array}$ & $\begin{array}{r}50 \\
28 \\
0\end{array}$ & $\begin{array}{r}50 \\
26 \\
0\end{array}$ \\
\hline plants & $\begin{array}{c}\text { No. of insects injected } \\
\text { No. of insects survived } \\
\text { for } 11 \text { days } \\
\text { No. of insects infected } \\
(\%)\end{array}$ & $\begin{array}{c}60 \\
19 \\
15 \\
(79)\end{array}$ & $\begin{array}{c}60 \\
13 \\
11 \\
(85)\end{array}$ & $\begin{array}{r}50 \\
20 \\
8 \\
(40)\end{array}$ & $\begin{array}{r}50 \\
25 \\
7 \\
(28)\end{array}$ & $\begin{array}{r}50 \\
20 \\
2 \\
(10)\end{array}$ & $\begin{array}{r}50 \\
20 \\
0\end{array}$ & $\begin{array}{r}50 \\
14 \\
0\end{array}$ & $\begin{array}{l}- \\
-\end{array}$ \\
\hline
\end{tabular}

Table 4. Effect of heat on RRSV

\begin{tabular}{l|r|r|r|r|r|r|r}
\hline \hline \multicolumn{1}{c|}{ Temperature (C) } & (Control) & 40 & 50 & 60 & 70 & 80 & 90 \\
\hline No. of insects injected & 50 & 50 & 50 & 50 & 50 & 50 & 50 \\
No. of insects survived for 11 days & 15 & 19 & 28 & 19 & 28 & 21 & 23 \\
No. of insects infected & 9 & 14 & 16 & 0 & 0 & 0 & 0 \\
$\quad(\%)$ & $(60)$ & $(73)$ & $(57)$ & & & & \\
\hline
\end{tabular}

24 hrs.. As shown in Table 2, RRSV in the crude sap remains infective even after 7 days at $4 \mathrm{C}$.

Effect of Dilution. Diseased rice leaves and brown planthoppers fed on diseased rice plants for 2 weeks were used for the experiments. The diseased leaves were ground in 10 volumes $(\mathrm{v} / \mathrm{w})$ of $0.1 \mathrm{M}$ ammonium acetate buffer, and then diluted. The exposed insects (about $30 \%$ of the exposed brown planthoppers were the active transmitters), approximately $0.2 \mathrm{~g}$ of 110 insects, were macerated in $20 \mathrm{ml}$ of $0.1 \mathrm{M}$ ammonium acetate buffer, and then diluted. Each viral preparation was injected into healthy insects. The results shown in Table 3 indicated that dilution end point of RRSV in extracts from diseased rice leaves was $10^{-5}$, while that from viruliferous insects was $10^{-6}$.

Effect of Heat. The extracts from the diseased plants were diluted in 2 volumes $(\mathrm{v} / \mathrm{w})$ of $0.1 \mathrm{M}$ ammonium acetate buffer, and were filled in glass tubes (about $10 \times$ 
Table 5. Effect of freezing and thawing on RRSV

\begin{tabular}{c|c|c|c|c}
\hline $\begin{array}{c}\text { Freezing and } \\
\text { thawing }\end{array}$ & $\begin{array}{c}\text { No.of insects } \\
\text { injected }\end{array}$ & $\begin{array}{c}\text { No.of insects } \\
\text { survived } \\
\text { for 11 days }\end{array}$ & $\begin{array}{c}\text { No.of insects } \\
\text { infected }\end{array}$ & $(\%)$ \\
\hline 1st & 50 & 26 & 23 & $(89)$ \\
2nd & 50 & 30 & 21 & $(70)$ \\
3rd & 50 & 30 & 22 & $(73)$ \\
\hline
\end{tabular}

Table 6. Effect of hydrogen-ion concentration on RRSV

\begin{tabular}{c|c|c|c|c}
\hline $\mathrm{pH}$ & $\begin{array}{c}\text { No. of insects } \\
\text { injected }\end{array}$ & $\begin{array}{c}\text { No. of insects } \\
\text { survived } \\
\text { for 11 days }\end{array}$ & $\begin{array}{c}\text { No. of insects } \\
\text { infected }\end{array}$ & $(\%)$ \\
\hline 5 & 50 & 15 & 7 & $(47)$ \\
6 & 50 & 11 & 9 & $(82)$ \\
7 & 50 & 18 & 12 & $(67)$ \\
8 & 50 & 10 & 8 & $(80)$ \\
9 & 50 & 15 & 11 & $(73)$ \\
\hline
\end{tabular}

$0.3 \mathrm{~cm}$ ) plugged at both end with rubber stoppers. The tubes were heated at $40,50,60,70,80$, and $90 \mathrm{C}$ for 10 minutes in hot water, and then rapidly cooled in running tap water. Each fluid was injected into healthy nymphs. In Table 4, the infectivity of RRSV in crude extracts was lost at 60 $\mathrm{C}$, but remains infective at $50 \mathrm{C}$. Effect of Freezing and

Thawing. The extract from the diseased leaves in 2 volumes $(\mathrm{v} / \mathrm{w})$ of $0.1 \mathrm{M}$ ammonium acetate buffer, was frozen at $-30 \mathrm{C}$, and then thawed at room temperature. Freezing and thawing of the crude extract was repeated 3 times, and

the preparations were injected into virus-free insects. As shown in Table 5, the infectivity was not markedly changed after three times of freezing and thawing.

Effect of Hydrogen-ion Concentration. The diseased leaves were ground in $0.1 \mathrm{M}$ ammonium acetate buffer at different hydrogen-ion concentration from $\mathrm{pH} 5$ to 9. Each extract was then injected into virus-free insects. The result shown in Table 6 indicated that the virus was stable at $\mathrm{pH} 6$ to 9 , but slightly decreased its infectivity at $\mathrm{pH} 5$.

Previous studies on RRSV indicated that the insect vector is capable of acquiring the virus by artificial injection ${ }^{4}$. Therefore, it became possible to work further studies on the properties of RRSV by this method. The results obtained in this experiment represent that RRSV is seemingly stable in the buffer solutions at different $\mathrm{pH}$ values ranging between $5-9$, at relatively low temperature $(4 \mathrm{C})$, and repeated freezing and thawing. Infectivity of the extracts from the viruliferous insects is 10 times higher than that of the extracts from the diseased plants. Thermal inactivation of the virus at $60 \mathrm{C}$ indicates that the virus is not highly resistant to heat.

Shikata $e t a l^{6}$, according to it's transmission mode and morphology of the virions, pointed out that RRSV most likely belonged to planthopper borne sub group of plant reovirus group. Properties of RRSV obtained in this experiments almost agree with those of rice black-streaked dwarf virus, which is one of the members of the subgroup.

(Received February 19,1979)

6) Shikata, E., T. Senboku, K. Kamjaipai, T. G. Chou, E. R. Tiongco, and K. C. Ling. (1979). Ann. Phytopath. Soc. Japan $45: 436-443$. 